\title{
Competencies, Capabilities and the Neoschumpeterian Tradition
}

\author{
Augier, Mie-Sophia; Teece, David J.
}

Document Version

Final published version

Publication date:

2004

\section{License \\ CC BY-NC-ND}

Citation for published version (APA):

Augier, M-S., \& Teece, D. J. (2004). Competencies, Capabilities and the Neoschumpeterian Tradition.

Link to publication in CBS Research Portal

\section{General rights}

Copyright and moral rights for the publications made accessible in the public portal are retained by the authors and/or other copyright owners and it is a condition of accessing publications that users recognise and abide by the legal requirements associated with these rights.

\section{Take down policy}

If you believe that this document breaches copyright please contact us (research.lib@cbs.dk) providing details, and we will remove access to the work immediately and investigate your claim. 
Papers in Organization, No. 52, 2004

No. 52

Competencies, Capabilities and

the Neoschumpeterian Tradition ${ }^{1}$

Mie Augier \& David J. Teece

\footnotetext{
${ }^{1}$ Mie Augier is post doctoral fellow and David Teece is Professor at the Institute of Management, Innovation and Organization Haas School of Business University of California, Berkeley. For correspondence, please contact augier@stanford.edu. Comments from and discussions with Giovanni Dosi, James March and Sid Winter are gratefully acknowledged; as is the skillful assistance of Patricia Lonergan in completing this paper.
} 
Papers in Organization No. 52 ISSN 0906-0510

Copyright (C) 2004

New Social Science Monographs

Department of Organization and Industrial Sociology

Copenhagen Business School

Solbjerg Plads 3

DK-2000 Frederiksberg, Denmark

Phone: +45 38152815

Fax: $\quad+4538152828$ 


\section{Papers in Organizations - Editor's Foreword}

The purpose of the series Papers in Organization is to work as a stepping-stone towards final publication in scientific journals. As such, PIO is a working-paper series, yet with a distinct position in the process towards final publication. The aim of PIO is to be the final steppingstone in that process:

- For the author PIO should add value to the work in progress through the editorial process. A publication in PIO is thus also a measure of the quality of the work - it is no longer simply a draft or an informal contribution to debates, but a work close to final publication.

- For the reader PIO should be a good place to be if one wants to keep track of contemporary research within the international field of organization studies. Indeed, many of the papers are manuscripts, which have been submitted to social science journals and as such appear in a rather final stage of completion. Others may contribute with empirical results from ongoing research projects or may in a more theoretical sense contribute to current academic disputes.

In this paper, Mie Augier and David Teece outline the history and development of the ideas underlying an emerging approach within strategic management research: the dynamic capabilities framework. The framework was first outlined by Teece and Pisano (1994), and in the present paper elaborated further so the reader will be able to appreciate some of the most important intellectual resources underpinning it, such as the work of Schumpeter, Penrose, Williamson, Cyert and March, Rummelt, Nelson and Winter. Although listed as intellectual resources by the authors, they also turn (some of) them into a topic for further discussion. For example, Augier and Teece identify not only the merits but also the limitations of transaction costs economics. In this way, the authors pave the way for a more dynamic framework while drawing upon organization theory and scholars like Cyert and March (a behavioral theory of the firm) and Nelson and Winter (an evolutionary theory of economic change). In the dynamic capability framework firms and markets co-evolve. Managers are now allowed to perform distinct strategic roles in shaping both firms and their markets, e.g. through asset- selection and orchestration, including also the task of allocating resources between exploitation and exploration.

Kjell Tryggestad/Søren Christensen

Editors 


\section{Introduction}

There is wide agreement that Joseph Schumpeter's ideas helped initiate or at least energize many developments in twentieth century economics. These include evolutionary economics, organization theory, the theory of technological change, and, of course, entrepreneurship. Various neoschumpterian traditions have also emerged in the field of business and corporate strategy. The business firm has been conceptualized by strategy scholars as consisting of bundles or "portfolios" of fixed assets and (production) competencies/capabilities. ${ }^{2}$ In recent years these ideas have become integrated into theories of the firm and economic organization. Indeed, the competences and capabilities tradition have garnered wide currency and is now generally accepted (Teece, 1982, 1986; Rumelt, 1984; Dosi, Nelson and Winter, 2000; Winter, 2000, 2003; Teece and Pisano, 1994, Teece et al 1997; Teece, 2003). ${ }^{3}$

\footnotetext{
2 Although the idea and terminology of organizations as bundles of competencies dates back to Oskar Morgenstern (1951), the more well known originator of the term was Philip Selznick (1957). Selznick introduced the idea of a firm's 'distinctive competence'; and Prahalad and Hamel (1990) popularized the idea of the 'core competencies' of the organization. For a discussion of some of these developments, see Dosi, Nelson and Winter (2000).

3 Richardson (1972) relied on Edith Penrose's (1959) idea of the firm as a collection of resources yielding various productive services. As Richardson (1972, p. 888) noted: "It is convenient to think of industry as carrying out an indefinitely large number of activities, activities related to the discovery and estimation of future wants, to research, develop-
}

There are both static and dynamic versions of the competences and capabilities tradition. Whereas the lineage of static versions of the capabilities framework can be traced to Ricardo, the lineage of dynamic versions can be attributed to Schumpeter (Teece et al, 1997, 2003). Scholars in strategic management, organizational theory, organizational economics, sociology, and innovation studies have embraced the dynamic version of capabilities with considerable enthusiasm.

This paper sketches the history of the development of the ideas underlying modern approaches to competencies and (dynamic) capabilities. ${ }^{4}$ In addition to providing a coherent framework for studying strategic management under conditions of uncertainty, rapid technological change and ambiguity, the dynamic capabilities framework is also well suited to the analysis of learning, thereby facilitating the integration of economic, organizational, and strategic

ment, and design, to the execution and co-ordination of processes of physical transformation, the marketing of goods, and so on. And we have to recognize that these activities have to be carried out by organizations with appropriate capabilities, or, in other words, with appropriate knowledge, experience, and skills”.

\footnotetext{
${ }^{4}$ For a history of the field of strategy in general, see Rumelt, Schendel and Teece (1994). The present paper focuses more narrowly on the history of (dynamic) capabilities and competencies within strategic management. More specific discussions of the nature of dynamic capabilities are found in Winter (2003) and Teece (2003).
} 
issues (Levinthal and March, 1993; Winter and Zollo, 2002).

\section{Antecedents and brief history}

\subsection{Introduction}

The field of strategic management has in recent years leveraged off of theories of economic organization in general and theories of the firm in particular. This was not always so. When Rumelt (1984) identified "a strategic theory of the firm" and pronounced that the study of business strategy must take off from economic theories of the firm, the linkages between economic theories of the firm and strategic management were either weak or non-existent. Tensions existed and in many respects still remain, between the neoclassical theory of the firm and strategic management. This is because of the cavalier treatment in economics of know-how, the static focus of neoclassical theory, and the strong behavioral assumptions around (hyper)rationality embedded in neoclassical theory (Winter and Teece, 1984; Teece, 1984; Simon, 1993).

Over the past 50 years, some progress had been made in the social sciences to help craft more realistic foundations for the theory of the firm. For instance, the ideas of Simon, Cyert and March on 'bounded rationality', opportunistic behavior, and routines were significant inputs for the emerging perspectives of transaction cost eco- nomics and evolutionary economics. Further, it had long been in the tradition of neoschumpeterian economists to emphasize innovation, technological change, and evolution. And in the mid 1980s, strategy scholars began to realize the usefulness of these developments in understanding firm behavior. For example, Teece (1984) argued that the evolutionary ideas of Nelson and Winter would help in providing a theory of the firm's distinctive competencies. Routines could be thought of as the skills of the organization, and the firm as an entity with a limited range of capabilities based on its available routines and physical assets. The emphasis in this emerging literature on routines introduces the idea of path dependency; a firms capabilities are defined very much by where it has been in the past and what it has done; and its current performance is a function of engrained repertoires (Dosi, 1988; Teece, 1984; March, 1994). Path dependencies and established technological trajectories shape the opportunities faced by firms. ${ }^{5}$

\footnotetext{
${ }^{5}$ Many writers have pointed to Schumpeter's ideas of 'creative destruction' underlying the modern emphasis on technological change. However, it is worth noting that Schumpeter didn't reserve the term for just technological change; for him, it was useful for analyzing many areas of the economy. As he noted: "This concept covers the following five cases: (1) The introduction of a new good-that is one with which consumers are not yet familiar-or of a new quality of a good. (2) The introduction of a new method of production, that is one not yet tested by experience in the branch of manufacture concerned, which need by no means be founded upon a discovery scientifically new, and can also exist in a
} 
In order to position neoschumpeterian ideas on competences and capabilities, we summarize below relevant theories in organizational economics/theories of the firm. Our purpose is to compare and contrast them to dynamic capabilities.

Dynamic capabilities refer to the particular (non-immitability) capacity firms have to shape, reshape, configure and reconfigure those assets so as to respond to changing technologies and markets. Dynamic capabilities, therefore, relate to the firm's ability to adapt in order to generate and exploit internal and external firm specific competences, and to address the firms changing environment (Teece et al, 1997). As Collis (1994) and Winter (2003) note, one element of dynamic capabilities is that they govern the rate of change of ordinary capabilities. ${ }^{6}$ If a firm possesses resources/competences but lacks dynamic capabilities, it has a chance to make a competitive return for a short period, but superior returns cannot be

new way of handling a commodity commercially. (3) The opening of a new market, that is a market into which the particular branch of manufacture of the country in question has not previously entered, whether or not this market has existed before. (4) The conquest of a new source of supply of raw materials or half-manufactured goods, again irrespective of whether this source already exists or whether it has first to be created. (5) The carrying out of the new organization of any industry, like the creation of a monopoly position (for examplethrough trustification) or the breaking up of a monopoly position. (Schumpeter, 1934, p. 66).

${ }^{6}$ For the particulars on the specific nature of different types of dynamic capabilities, see Teece (2003). sustained It may earn Ricardian (quasi) rents, but such quasi rents will be competed away, often rather quickly. It cannot earn Schumpeterian rents because it hasn't built the capacity to be continually innovative. Nor is it likely to be able to earn monopoly (Porterian) rents since these require exclusive behavior or strategic manipulation (Teece, 2003).

An illustration of some of the issues involved in the dynamic capability framework is found in the story of the British pop group, Spice Girls. The group made pophistory in the late 90s with their successes (being the first female group to win 9 number 1 hit-singles - only Elvis, Cliff Richard, Madonna and the Beatles ever had more). The band was the result of two entrepreneurial and innovative management gurus (Bob and Chris Herbert) who in 1994 handpicked the five members to sing in a team (at first called 'Touch', the band name (and the manager) was changed in 1996). After a few years of success, the band broke up and the individual band members tried to pursue solo careers. However, none of them were able to replicate the success of the band as a team (or organization), and popindustry experts commented that only if the band got together again would they be able to return to the success of previous years. In other words, it was the dynamic orchestration of individual skills and knowledge in 
the organization of the band that created the success. Once apart, their individual capabilities were no longer productive. The solo careers of several of the Spice Girls ended abruptly.

\subsection{Relationship to Transaction Cost Theory $^{7}$}

The transactions cost approach is widely accepted as a framework for understanding economic organization. This perspective sees markets and hierarchies as alternative mechanisms for organizing transactions. In order to economize on transaction costs, production is frequently required to be organized in firms. Transaction cost economics builds on the assumptions of bounded rationality and opportunism (Williamson, 1975, 1985). Contractual efficiency is impaired when switching costs have to be incurred to change suppliers. In such circumstances, vertical integration is likely to be superior according to transaction cost analysis. $^{8}$

\footnotetext{
${ }^{7}$ Parts of this section draws on Teece (2003)

${ }^{8}$ The link between transaction cost economics and strategy was present already when Williamson (1975) demonstrated the relevance of transaction cost ideas to issues of corporate strategy (such as efficient firm boundaries); and the ChandlerWilliamson M-form hypothesis quickly became a key insight in the strategic management field, in particular after being supported by a number of empirical studies, beginning with Armour and Teece (1978).
}

There is much utility and exploratory power in the transaction cost framework. However, the contractual scheme upon which it is built deals with existing resources and does not examine how new resources are discovered, how they are accumulated, and how firms learn. The structure and behavior of the modern business firm cannot be fully explained by appealing to transaction costs alone. The focus for the "main case" in transaction cost economics is governance - i.e. how things should be organized. This is an important element of management; but it isn't the main concern of management scholars or practitioners. While it is important to have the right governance, it is of equal - if not greater - importance to make the right investment choices, select the right assets to “govern”, and establish the correct business model. Superior organizational capabilities require not just astute initial asset selection; they also require continuous reconfiguration and improvement. The transaction cost framework, by contrast is primarily about asset or value protection, not value creation ${ }^{9}$

\footnotetext{
9 The way in which governance (choice of firm boundary) issues do come into play in strategic management is well illustrated in Teece (1986), where there is extensive discussion of complementary assets and whether or not these should be internalized. Deciding whether to "own" or "rent" (i.e. integrate or outsource) complementary assets depends on whether the assets were available in competitive supply. A concern to focus on is the distribution of gains (and losses) between the innovator and the owners of the complementary assets. Williamson also explores appropriability through ex
} 
Williamson clearly recognizes that even in the world of transaction cost economics, governance costs are not the only costs that are relevant to the firm. "Production costs" are mentioned, but not analyzed deeply. However, much lies within "production costs" that economists and management scholars need to understand. They include not just operational issues, but strategic issues too. Some production related issues are operational - - such as the establishment of flexible procurement, enabling the firm to take advantage of changing competitive pricing - and some highly strategic, such as whether or not to invest in a new plant, whether to advance a new generation of products now, later, or never. Clearly, the performance of a business is going to be very significantly impacted by production and investment choices, as well as by governance choices. ${ }^{10}$

poste recontracting. However, the appropriability issues of most concern to business managers do not come from a pure form of what Williamson calls "the fundamental transformation". With this transformation, an exante large numbers bargaining situation is transformed into a small numbers situation after idiosyncratic irreversible investment assets are deployed, and recontracting hazards result. Rather, it is simply that technological innovation changes the demand for certain inputs (resources) and their complements. The entity that can cleverly bargain to obtain a "long" position in those assets on favorable terms will be able to appropriate a greater share of the gains from innovation. Put differently, in Teece (1986), it is asset selection based on value creation that shapes firm boundary selection issues not just the minimization of transaction costs.

${ }^{10}$ For instance, Langlois (1992) highlights the case of the diesel electric locomotive, where in the 1920s, Charles Kettering had developed advanced light-
In short, the (dynamic) capabilities framework suggests that the scope of the firm cannot be explained just by transaction cost considerations. Rather, asset selection (internalization) decisions must also make reference to complementarities and cospecialization for reasons of scope economies, and appropriability (Teece, 2003).

The complementarity between transaction cost economics and dynamic capabilities has been recognized by Williamson, Teece and Winter. ${ }^{11}$ Williamson notes that transaction cost and internal firm perspectives "deal with partly overlapping phenomenon, often in complementary ways” (1999, p. 1098). Indeed, the very first empirical study to show the predictive power of asset specificity in setting firm boundaries (Monteverde and Teece, 1982) also showed that

weight diesel technology at the G.M. Labs. The earliest use was in submarines. Alfred P. Sloan, GM's Chairman, saw the possibility of applying the technology to make diesel electric locomotives. (Steam power was, at the time, completely dominant). G.M. needed capabilities resident in the locomotive manufacturers, and at Westinghouse Electric. As Langlois notes: "The three sets of capabilities might have been combined by some kind of contract or joint venture. But the steam manufacturers - Alco, Baldwin, and Lima - failed to cooperate. This was not, however, because they feared hold-up in the face of highly specific assets. Rather, it was because they actively denied the desirability of the diesel and fought its introduction at every step. General Motors was forced to create its own capabilities in locomotive manufacturer (p. 115)."

${ }^{11}$ For other relevant and informative - although perhaps a bit more skeptical - discussions of the complementarity between transaction cost theory and capability ideas, see Dosi and Marengo, 2000; Dosi, 2004. 
even greater predictive power was associated with cospecialization or "systems integration” causing Teece (1990) to observe that: [I]n order to fully develop its capabilities, transaction cost economics must be joined with a theory of knowledge and production (p. 59; also see Winter, 1988). ${ }^{12}$ As a result, scholars began looking elsewhere to develop more robust theories of the firm. Behavioral and evolutionary economics has been recognized as another source of useful insights.

\subsection{Relationship to the Behavioral The- ory of the Firm}

The behavioral theory of the firm is a more dynamic perspective than transaction cost theory. It wasn't intended as a theory of strategy; but several insights from the behavioral perspective are used in both the resource based view (Barney, 1991) and dynamic capability theory (Teece et al, 2002).

The behavioral theory is built around a political conception of organizational goals, a bounded rationality conception of expectations, an adaptive conception of rules and aspirations, and a set of ideas about how the interactions among these factors affect de-

\footnotetext{
${ }^{12}$ Various studies have now shown that competences/cospecialization also play a role in the make or buy decision (Walker and Weber, 1984; Jacobides and Hitt, 2001).
}

cisions in a firm (Cyert and March, 1963). Whereas goals in neoclassical theory are pictured as given alternatives each with a set of consequences attached, goals within behavioral theory are pictured as reflecting the demands of a political coalition, changing as the composition of that coalition changes. Thus, the theory treats the demands of shareholders, managers, workers, customers, suppliers, and creditors as components of the operational goals of a firm. At the same time, not all goals are salient at all times. Rather, specific goals are evoked by the presence of coalition members in the decision neighborhood, by the divisional organization of the firm, and by the recognition of particular problems. Aspirations with respect to each dimension of the goals were pictured as changing in response to the experience of the organization and its components as well as the experience of others to whom they compare themselves. Thus, it is the dynamic nature of aspirations which enables the generation of new decision alternatives. Therefore, the firm must engage in active search and imagination to create sustainable strategic opportunities (Winter, 2000).

In the behavioral view, agents have only limited rationality, meaning that behavior in organizations is intendedly rational; neither emotive nor aimless (March and Simon, 1958. Since firms are seen as heterogene- 
ous, boundedly rational entities that have to search for relevant information, expectations in the behavioral theory is portrayed as the result of making inferences from available information, involving both the process by which information is made available and to the processes of drawing inferences. Since information is costly, it is generated by search activity. The intensity of search depends on the performance of the organization relative to aspirations and the amount of organizational slack (March and Simon, 1958, pp. 47-52). The direction of search is affected by the location (in the organization) or search activity and the definition of the problem stimulating the activity. Thus, the search activity of the organization furthers both the generation of new alternative strategies, and facilitates the anticipation of uncertain futures.

Decision-making in the behavioral theory is seen as taking place in response to a problem, through the use of standard operating procedures and other routines, and also through search for an alternative that is acceptable from the point of view of current aspiration levels for evoked goals. Choice is affected, therefore, by the definition of a problem, by existing rules (which reflect past learning by the organization), by the order in which alternatives are considered (which reflects the location of decision making in the organization and past experi- ence), and by anything that affects aspirations and attention. ${ }^{13}$

Cyert and March (1963) emphasized the uniqueness in firms; organizations and organizational actors differ in terms of their aspirations, their knowledge, and their decisions. In terms of relevance to strategy, the most basic contribution of the behavioral theory of the firm is the importance of firm heterogeneity (Teece et al, 2002). Winter (2000) also uses the ideas on satisficing and dynamic aspiration levels to suggest an ecological and evolutionary perspective in which learning is a dynamic capability. Dynamic capability theory builds on behavioral ideas of adaptation and dynamic character of expectations and goals (Teece et al 2002).

\subsection{Relationship to Evolutionary ideas of the firm (and strategy)}

The evolutionary theory of the firm goes back to (at least) Alfred Marshall's con-

\footnotetext{
${ }^{13}$ Within this framework, four concepts were developed. The first is the quasi-resolution of conflict, the idea that firms function with considerable latent conflict of interests but do not necessarily resolve that conflict explicitly. The second is uncertainty avoidance. Although firms try to anticipate an unpredictable future insofar as they can, they also try to restructure their worlds in order to minimize their dependence on anticipation of the highly uncertain future. The third concept is problemistic search, the idea that search within a firm is stimulated primarily by problems and directed to solving those problems. The fourth concept is organizational learning. The theory assumes that firms learn from their own experiences and the experiences of others.
} 
struction of the industry equilibrium, which combined a population of firms in disequilibrium with industry level supply-demand equilibrium, frequently using biological analogies. ${ }^{14}$ A representative firm is hypothesized to bridge the dynamic analysis of firm level and the static industry level. "[F]irms rise and fall”, Marshall said, "but the representative firm remains always of the same size" (1925, p. 367).

Many ideas significant for the development of the evolutionary view were also introduced by Joseph Schumpeter. For instance, although the idea of rules based or bounded rationality became associated with Simon (1955) and March and Simon (1958) (and then later embedded in Nelson and Winter (1982)), Schumpeter was early to recognize that bounded rationality is necessary for a theory of innovation and dynamics:

\footnotetext{
${ }^{14}$ As Marshall explains in his 'Principles': “we may read a lesson from the young trees in the forest as they struggle upwards through the benumbing shade of their older rivals. Many succumb on the way, and a few only survive; those few become stronger with every year, they get a larger share of light and air with every increase of their height, and at last in their turn they tower above their neighbors. One tree will last longer in full vigor and attain a greater size than another; but sooner or later age tells on them all. And as with the growth of trees, so was it with the growth of business as a general rule before the great recent development of vast joint-stock companies, which often stagnate, but do not readily die” (Marshall, 1925, p. 315-316). For excellent discussions of Marshall's evolutionary ideas, see the work of Brian Loasby $(1976,1989)$.
}

"The assumption that conduct is prompt and rational is in all cases a fiction. But it proves to be sufficiently near to reality, if things have time to hammer logic into men. Where this has happened, and within the limits in which it has happened, one may rest content with this fiction and build theories ... Outside of these limits our fiction loses its closeness to reality. To cling to it there also as traditional theory does, is to hide an essential thing and to ignore a fact which, in contrast with other deviations of our assumption from reality, is theoretically important and the source of the explanation of phenomena which would not exist without it” (Schumpeter, 1934, p. 80).

Evolutionary ideas also surfaced during the profit maximization debate in economics involving Fritz Machlup, Milton Friedman (1953), Armen Alchian (1950, 1953) and Edith Penrose (1952, 1953). The debate (concerning, among other things, the role of intentionality in economic selection and the use of a population of heterogeneous firms as a basis for selection) led to the formal evolutionary work by Winter (1964, 1971, 1975). ${ }^{15}$

\footnotetext{
${ }^{15}$ In contrast to the position of Friedman and others, evolutionary theory emphasizes that selection does not always lead to efficient outcomes because firms operate in a context or environment of other firms. "In fact", Nelson and Winter writes, "there is good reason to expect the opposite, since selection forces may be expected to be 'sensible' and to trade off maladaptation under unusual or unencountered conditions to achieve good adaptations to conditions
} 
Despite these prominent predecessors, an evolutionary view of the firm wasn't developed until decades later. In what was first intended to be entitled "a Neo Schumpeterian Theory of the Firm”, Nelson and Winter (1982) integrated insights from Schumpeter with ideas from Armen Alchain, Friederich Hayek and Cyert and March (1963). ${ }^{16}$

The firm in their view is seen as a profit seeking entity whose primary activities are to build (through organizational learning processes) and exploit valuable knowledge assets. Firms in this view also come with 'routines' or 'competencies', which are recurrent patterns of action which may change through search and learning. Routines will seldom be 'optimal' and will differ among agents and behaviors cannot be deduced from simply observing the environmental signals (such as prices) that agents are exposed to. This variety drives the evolutionary process since firms articulate rent-seeking strategies on the basis of their routines and competencies and compe-

frequently encountered. In a context of progressive change, therefore, one should not expect to observe ideal adaptation to current conditions by the products of evolutionary change” (1982, p. 154).

\footnotetext{
16 The title, 'Towards a Neoschumpeterian Theory of the Firm' was the title of Winter's first working paper, written at the RAND Corporation (Winter, 1968), which became the main basis of the Nelson and Winter collaboration, leading to Nelson and Winter (1982).
}

tition in the product market constitutes an important part of the selection environment of confronting firms.

In order to fully understand these (and related) issues and their implications for theories of the firm and strategic management, scholars have appealed to the idea of firms as knowledge-bearing and learning entities; and a notion of the firm as endogenously creating its productive opportunity set. This line of thought was provided by Edith Penrose (1959). Penrose (1959) was the first to argue that the firm is a repository of capabilities and knowledge and that learning is central to firm growth and to provide a theory of firms that explicitly makes room for issues relating to the production and exploitation of productive knowledge. Productive knowledge is often related to other organizational (material) assets. ${ }^{17}$ The firm, she said, is "both an administrative organization and a collection of productive resources, both human and material" (p. 320). The services rendered by these resources are the primary inputs into a firm's

\footnotetext{
${ }^{17}$ As Penrose writes: "For physical resources the range of services inherent in any given resource depends on the physical characteristics of the resource, and it is probably safe to assume that at any given time the known productive services inherent in a resource do not exhaust the full potential of the resource... The possibilities of using services change with changes in knowledge.. there is a close connection between the type of knowledge possessed by the personnel in the firm and the services obtainable from its material resources” (1959, p. 76).
} 
production processes and are firm specific in the sense that they are a function of the knowledge and experience that the firm has acquired over time. When services that are currently going unused are applied to new lines of business, these services also function as a growth engine for the firm. Learning enables the organization to use its resources more efficiently. As a result, even firms that maintain a constant level of capital may nevertheless be able to grow as services are freed up for new uses as a result of organizational learning. ${ }^{18}$

\section{The Evolving Dynamics of Organiza- tional Capabilities}

Because firms face strategic decisions on the basis of past history, it is natural to view questions relating to the development of strategy and competences in an evolutionary setting (Simon, 1993; Winter, 2000). The most recent chapter in the history of competencies and capabilities is the dynamic capabilities approach, which seeks to provide a coherent (and evolutionary)

\footnotetext{
18 Teece's paper on the multiproduct firm (Teece, 1982) was the first to apply Penrose's ideas to strategic management issues. He focused on her observation that human capital in firms is usually not entirely 'specialized' and can therefore be (re)deployed to allow the firm's diversification into new products and services. He also used Penrose's view that firms possess excess resources which can be used for diversification. Later, Wernerfelt (1984) cites Penrose for "the idea of looking at firms as a broader set of resources ... [and] the optimal growth of the firm involves a balance between exploitation of existing resources and development of new ones"
}

framework, which can both integrate existing conceptual and empirical knowledge and facilitate prescription. First outlined in Teece and Pisano (1994) and elaborated in Teece et al (1997), a paper which had circulated for seven years as a working paper, ${ }^{19}$ the dynamic capabilities approach builds upon the theoretical foundations provided by Schumpeter (1934), Penrose (1959), Williamson (1975, 1985), Cyert and March (1963), Rumelt (1984), Nelson and Winter (1982), Teece (1982) and Teece et al (1994). In particular, it is consistent with the Schumpeterian view that the emergence of new products and processes results from new combinations of knowledge. In a similar vein, it is argued in the dynamic capabilities approach that competitive success arises from the continuous development and reconfiguration of firm-specific assets (Teece and Pisano, 1994; Teece et al, 1997). Whereas Penrose and the resourcebased scholars recognize the competitive importance of firm-specific capabilities, researchers of the dynamic capabilities approach attempt to outline specifically how organizations develop and renew internal competencies. Thus, the latter approach is concerned with a subset of a firm's overall capabilities, namely, those that allow firms

\footnotetext{
${ }^{19}$ This explains why references to dynamic capabilities began before the publication of this paper. In the early to mid 90's, the working paper versions were quoted. See for instance Mahoney and Pandian (1992).
} 
to create new knowledge and to disseminate it throughout the organization.

The dynamic capability perspective follows Hayek (1945) (and the behavioral and evolutionary theorists) in emphasizing that coordination as an economic problem only occurs because of change. In a static environment a short period of "set up" would be required to organize economic activity; but absent change in consumer tastes or technology, economic agents (both traders and managers) would sort out the optimal flows of goods and services (together with methods of production). Thereafter, there would be no need for their services.

Now introduce change. If there were a complete set of forward and contingent claims markets, adjustments would occur automatically; absent a complete set of futures and contingent claims markets, there is the need for economic agents to engage in trading activities, and for managers/entrepreneurs to "integrate, build, and reconfigure internal and external competences to address rapidly changing environments” (Teece et al., 1997). Coordinating and adapting effectively to changing environments (Cyert and March 1963) is an element of a firm's dynamic capabilities. Barnard (1938) and Richardson (1960) were early to develop these themes.
Chester Barnard's view of the firm was that it was fundamentally a structure to achieve coordination and adaptation. But as Williamson (1990) observes, Barnard did not compare the firm to markets in terms of their coordinative or adaptive capabilities. One key difference is that the firm achieves coordination and adaptation with respect to non-traded or thinly traded assets; the market on the other hand enables rapid adaptation with respect to assets which are actively traded in thick markets (Teece, 2003).

However, dynamic capabilities involve much more than "coordination" and "adaptation”, and the functions of the (strategic) manager go beyond what Barnard and Williamson have identified. In particular, coordination and adaptation do not convey very well notions such as proactive search, selection and subsequent implementation of particular courses of action critical to firms' business strategies. Nor does it convey the importance of asset alignment, opportunity identification, and access to critical cospecialized assets. These are all critical elements of management's dynamic capabilities, and are important to value creation.

Put another way, the need for firms' to have dynamic capabilities stems from what can 
be thought of as "market failures". ${ }^{20}$ The "market failure" at issue is not due just to high transaction costs and contractual incompleteness. ${ }^{21}$ Rather, it is associated with the non-existence of certain markets and the need to identify, align, adapt, and coordinate activities and assets, especially complementary assets.

Complementarities frequently exist amongst assets used in the firm, and frequently exist with assets outside the firm. These complementarities are easy to manage when markets are thick, as standard purchase and sale agreements or term contacts ought suffice. But when markets are thin, or non-existent, alignment isn't necessarily achieved by trades. It's the job of the (strategic) manager to decide what investments are to be made and what assets are to be purchased and how complementarities are to be achieved. Inside the firm, the strategy manager can ensure that new task boundaries are created and existing ones

\footnotetext{
20 The use of the term "market failure" is only relative to the theoretical norm of absolute static and dynamic efficiency. Of course, a (private) enterprise economic system as a whole achieves an efficient allocation of resources, as strategic managers and the organization they lead are an inherent part of the economic system. However, the framework does highlight the fact that management systems and corporate governance must function well for a private enterprise market oriented system to function well.
}

\footnotetext{
${ }^{21}$ To the extent that transaction costs are relevant, it is of the dynamic variety (See Langlois 1992).
}

ignored. Under guidance from the strategy manager, the ability of (complementary) asset owners to block innovation can be eliminated through acquisition, or worked around through additional investment.

G.B. Richardson (1960) has remarked upon the information problems associated with achieving coordination and investment decisions. However, his focus is on industry level coordination of investment. He identified situations where limited information about competitor's investment decisions may impede efficient-investment. This is not the focus here. The essential coordination task identified in the dynamic capabilities framework is internal to the firm, though it may well involve strategic alliances with other firms too.

Needless to say, the proficient achievement of the necessary coordination is by no means assured inside the firm. Decision makers need information on changing consumer needs and technology. Such information is not always available; or if it is available, is likely to be incomplete, or highly subjective (Casson 2000, p. 119; Simon 1993). Managers are of course decision makers and they must collect information, analyze it, synthesize it, and act upon it inside the firm. Situations are dealt with in many ways, sometimes by creating rules, which specify how the organization will 
respond to the observations made (March and Simon, 1958). If this path is chosen, then rules may become codified and routinely applied (Casson 2000, p.129) whenever certain changes are detected. ${ }^{22}$ However, such rules need to be periodically revised for the firm to have dynamic capabilities.

In some circumstances, new information and new situations may be best dealt with by forming a new firm (Knight, 1921). ${ }^{23}$ Those who discover the new information, and can figure out the appropriate response, need not be the same individual(s) who start a new enterprise; but given the absence of a well functioning market for information about new market opportunities, the discoverer and the enterprise founder may need to be one and the same.

The coordinating and resource allocating capabilities featured in dynamic capabilities shape markets, as much as markets shape

\footnotetext{
${ }^{22}$ Casson argues that rule making is entrepreneurial, but that rule implementation is routine, and is characterized by managerial and administrative work.

${ }^{23}$ Frank Knight was (probably) the first to argue a distinct entrepreneurial theory of the firm (Langlois and Cosgel 1993). In particular, Knight thought of entrepreneurs as possessing different judgments (and different capacities for judgments) and acting upon (and profiting from) genuine uncertainty and unpredictability: "[I]t is true uncertainty which by preventing the theoretically perfect outworking of the tendencies of competition gives the characteristic form of 'enterprise' to economic organization as a whole and accounts for the peculiar income of the entrepreneur” (Knight 1921, p. 232).
}

firms (Chandler, 1990; Teece, 1993; Simon, 1991). Put simply, firms and markets coevolve. Hence, while the need for asset coordination and orchestration and associated investment choices may be the fundamental problem which the firm's dynamic capabilities help address, the firm's dynamic capabilities - particularly its ability to introduce new products and services into the market - not only shapes markets; it also requires firm-level responses by competitors, suppliers, and sometimes customers.

The emergence/development of markets is thus important for strategic management. Elsewhere (Teece,1998) the emergence of intermediate product markets was identified as a major leveler in competition, enabling more specialists firms to compete and provide a limited kind of innovation, called autonomous innovation. There are parts of the value chain which ought to be outsourced when well functioning intermediate (product) markets exist. ${ }^{24}$

\section{Research Agenda Implications}

'Competencies' and 'capabilities' are seductive concepts. They are significant parts

\footnotetext{
${ }^{24}$ The creation of intermediate markets is not readily explained by asset specificity concerns, as implied by transaction cost economics. The absence of standards, or simply the decisions by incumbent firms to size production so as to avoid the need to sell intermediate products are possible explanations for the enigma of markets for intermediate inputs.
} 
of many modern theories of organization and strategic management; yet there's considerable confusion about the precise nature of the concepts (Dosi, Nelson and Winter, 2000). Recent contributions have clarified the key ideas somewhat (Winter, 2003; Eisenhardt and Martin, 2000; Teece, 2003). The full implications for a research agenda are still to be explored; however, we can outline at least the following important implications for research theory of the firm and strategic management; and for issues relating to entrepreneurship/leadership.

\subsection{Strategic Management and the The- ory of the Firm}

Ronald Coase was well aware that economists have neglected the role of management in the theory of the firm when he noted that "economists have tended to neglect the main activity of the firm, running a business" (1988, p. 38). There is no role for the manager in the economic theory of the firm. Although Williamson claims that the role of management is "significant" in transaction cost economics (1999, p. 1101), his support for the assertion makes reference to the emphasis in transaction cost economics on the adaptive properties of organization, and recognition that management can exercise "fiat". This is clearly inadequate. In the dynamic capabilities framework, management plays distinctive roles in selecting and/or developing rou- tines, making investment choices, and in orchestrating non-tradable assets. This is a more robust role for management than transaction cost economics has so far afforded.

But whatever differences may exist in transaction cost economics with respect to the role of the manager, they pale next to models of the neoclassical firm in economics where managers and the management function have been blotted out. ${ }^{25}$ As Baumol puts it:

"Obviously, the entrepreneur has been read out of the model. There is no room for enterprise or initiative. The management group becomes a passive calculator that reacts mechanically to changes imposed on it by fortuitous external developments over which it does not exert, and does not even attempt to exert, any influence. One hears

\footnotetext{
${ }^{25}$ Consider the nature of the model of the firm. In its simplest form - the theoretical firm must choose among alternative values for a small number of well-defined variables; price, output, perhaps advertising outlay. In making this choice management is taken to consider the costs and revenues associated with each candidate set of values, as described by the relevant functional relationships, equations, and inequalities. Explicitly or implicitly the firm is then taken to perform a mathematical calculation which yields optimal (i.e., profit maximizing) values for all of its decision variables and it is these values which the theory assumes to be chosen - which are taken to constitute the business decision. There matters rest, forever or until exogenous forces lead to an autonomous change in the environment. Until there is such a shift in one of the relationships that define the problem, the firm is taken to replicate precisely its previous decisions, day after day, year after year.
} 
of no clever ruses, ingenious schemes, brilliant innovations, of no charisma or of any of the other stuff of which outstanding entrepreneurship is made; one does not hear of them because there is no way in which they can fit into the model” (Baumol, 1968, p. 67).

Winter and Teece (1984) likewise observed that entrepreneurship had been suppressed in the theory of the firm. Serious questions are raised with respect to the value of neoclassical models in management theory, management education, and, by implication, management practice.

\subsection{Strategic Management and Entre-} preneur (and leader-)ship

It is important to understand the role of management in the dynamic capabilities framework advanced above. If, as Winter (2003) and others suggest, dynamic capabilities are defined mainly around highlevel routines, perhaps the role of (strategic) management is reduced and relegated to selecting new routines. Certainly, if innovation becomes truly a routine in large firms, then the manager/intrapreneur has a modest role to play after the routines are in place. The framework presented above suggests a bigger role because it also refer- ences asset selection and asset orchestration as a part of dynamic capabilities.

In an economic system, principals and/or their agents must design and implement processes to manage change, must direct the reinvestment of cash flow, and must configure asset portfolios, including allocating resources between exploitation and exploration (March, 1991, 1994). They must also stand ready to reconfigure them as circumstances change. In a strict evolutionary views of the world, there is no specific agent and no hierarchy responsible for regulating the evolutionary process (Cohendet, Llerena and Marengo 2000).

However, in a less evolutionary view of the world, there is room for a managerial and entrepreneurial function. The manager/ entrepreneur need not be an individual; in the modern corporation it is a function. As Schumpeter (1949) noted: “The entrepreneurial function may be and often is filled cooperatively - in many cases, therefore, it is difficult or even impossible to name an individual that acts as "the entrepreneur." (pp. 71-72).

The manager/entrepreneur must articulate goals, set culture, build trust, and play a critical role in the key strategic decisions. Clearly the role of the entrepreneur and the 
manager overlap to a considerable extent. As Simon (1991) recognized:

"Especially in the case of new or expanding firms, the entrepreneur does not face an abstract capital market. He or she exerts much effort to induce potential investors to share the company's views (often optimistic) about its prospects. This executive is much closer to Schumpeter's entrepreneur than to the entrepreneur of current neoclassical theory. Whether the firm expands or contracts is determined not just by how its customers respond to it, but by how insightful, sanguine and energetic its owners and managers are about its opportunities" (p. 31).

The manager/entrepreneur plays a key role in achieving asset selection and the "coordination” of economic activity, particularly when complementary assets must be assembled. The manager/entrepreneur can bargain and negotiate and buy or sell or swap investments/assets, orchestrate internal assets (intrapreneurship) and transact with the owners of external assets (entrepreneurship). He is likely to have strong skills in working out new "business models", which define the architecture of new businesses (Chesbrough and Rosenbloom, 2002). The astute performance of this function will help achieve what Porter (1996) calls "strategic fit", not just with internally controlled assets, but with the assets of alliance partners. ${ }^{26}$ The manager/entrepreneur can also shape learning processes with the firm. These are not functions which can be achieved by markets divorced from managers/entrepreneurs.

Thus the entrepreneur/manager function in the dynamic capabilities framework is in part Schumpeterian (the entrepreneur introduces novelty and seeks new combinations) and in part evolutionary (the entrepreneur endeavors to promote and shape learning). Whether intrapreneur or entrepreneur, the function senses new opportunities and leads the organization forward to seize them. The entrepreneur/ manager must therefore lead. These are roles not recognized by economic theory; but these roles are the essence of dynamic capabilities and are critical to the theory of strategic management.

\footnotetext{
${ }^{26}$ As Porter (1996) notes, "[S]trategic fit among many activities is fundamental not only to competitive advantage but also to sustainability of that advantage. It is harder for a rival to match an array of interlocked activities than it is merely to imitate a particular sales force approach, match a process technology, or replicate a set of product features." (p. 73) [And] "when activities complement each other, rivals will get very little benefit from imitation unless they successfully match the whole system - frequent shifts in positioning are costly -strategy is creating a fit among a company's activities. The success of strategy depends on doing many things well - not just a few in an integrating among them. If there is not fit among activities, there is not distinctive strategy and little sustainability." (p. 77)
} 


\section{Conclusion}

Several decades with evolutionary theory has brought shifting focus on several fronts. Not only has areas such as economics, management and strategy become enriched with evolutionary ideas, but also concepts such as routines, competencies, capabilities and learning rose from neglected subfields to attain near parity with old concepts of organization and management theory; and ideas on competences and capabilities have begun to emerge as viable complements not only neoclassical economics, but also much of transaction cost theory (Dosi, 2004). Most of this new discussion takes place within the analytical framework of evolutionary (and neoschumpeterian) theory, broadly speaking.

Such a framework invites research on entrepreneurship, organizational learning and the role of the manager/leader of the firm. The dynamic capability view sets off from several evolutionary ideas and sees the firm as an incubator and repository for difficult to replicate assets; and technological and knowledge assets are central. Distinctive processes support the creation, protection, and augmentation of firm-specific assets and competences. These assets and competences reflect both individual skills and experiences as well as distinctive ways of doing things inside firms. To the extent that such assets and competences are diffi- cult to imitate and are effectively deployed and redeployed in the marketplace (reflecting dynamic capabilities), they can provide the foundations for competitive advantage.

Dynamic capability was intended in the beginning as a set of ideas around flexibility, adaptability, integration, disintegration, etc. Increasing focus on changing knowledge assets, technology, etc. has spurred increasing focus on organizational change and how environments and histories of business firms shape organizational forms, practices and competencies. As a result, the dynamic capability perspective seeks to explore how changes in the world are likely to result in changes in business firms, and how organizations can improve and survive by developing and positioning dynamic capabilities.

The dynamic capability perspective is still developing; we may even see it as 'preparadigmatic', in Thomas Kuhn's terminology. As a theoretical perspective, the dynamic capability framework offers an integrative methodology and perspective in which several theoretical traditions are used as tools for analyzing the dynamics of business organizations. Understanding and utilizing ideas from different traditions - transaction cost theory, evolutionary economics and behavioral theory - provides a unique intellectual platform for dynamic capabili- 
ties. Such an integrative approach is also consistent with Schumpter's view on using theories from the past as well as from the present to analyze economic growth and change:

"The time may have come ... to co-ordinate and to organize [different past theoretical traditions] work by means of comprehensive 'programs' and to provide, for the use of the individual research worker, orderly schemata of possible problems. It is here, and it its instrumental capacity, not as a master but as a servant of historical research, that theory may prove useful" (Schumpeter, 1947, p. 9).

The future relevance of competences and capabilities within strategic management will depend on whether future developments in the field will bring us closer to an empirically relevant paradigm, which can accommodate and address issues relating to the dynamics of the business enterprise. This in turn will depend on the ability of the scholars and ideas within strategic management to work together and for the research program to accommodate an interdisciplinary vision, and to be disciplined (March, 1996). Such a (interdisciplinary, yet disciplined) vision is the first step toward realizing a coherent program in strategic management; and we may see the dynamic capability program as taking the first important steps toward establishing a coherent and rigorous research program in strategic management. By integrating ideas from other traditions, the dynamic capability program sets a research agenda for future studies in strategic management. Future areas of research include (but are not limited to) the nature of the firm, strategic management and entrepreneur- and leadership.

\section{References}

Alchian, A. (1950) Uncertainty, Evolution, and Economic Theory, Journal of Political Economy 58, pp 211-222.

Alchian, A. (1953) Biological Analogies in the Theory of the Firm: Comment, American Economic Review 43 (4), pp 600-603.

Armour, H. and D.J. Teece (1978) Organizational structure and economic performance: A test of the multidivisional hypothesis, The Bell Journal of Economics 9(2), pp 106-122.

Barnard, C. (1938) The Functions of the Executive. Harvard University Press.

Barney J. (1991) Firm resources and sustained competitive advantage, Journal of Management 17(1), pp 99-120.

Baumol, W. (1968) Entrepreneurship in economic theory, American Economic Review 58(2), pp 64-71.

Casson, M. (2000) An entrepreneurial theory of the firm, in Foss, N. and V. Mahnke (eds) Competence, Governance, and Entrepreneurship. Oxford University Press.

Chandler, A. (1990) Scale and Scope. Belknap Press. 
Chesbrough, H. and R.S. Rosenbloom (2002) The role of the business model in capturing value from innovation: Evidence from Xerox Corporation's technology, Industrial and Corporate Change 11(3), pp 529-555.

Coase, R. H. (1988) The Nature of the Firm: Origin, Meaning, Influence, Journal of Law, Economics, and Organization 4(1), pp 3-47.

Cohendet, P., P. Llerna, and L. Marengo (2000) Is there a pilot in the evolutionary firm?, in Foss, N. and V. Mahnke op. cit.

Collis, D. J. (1994) Research note: How valuable are organisational capabilities? Strategic Management Journal 15, pp 143152.

Cyert, R. and J.G. March (1963) A Behavioral Theory of the Firm. Englewood Cliffs: Prentice Hall.

Dosi, G. (1988) Sources, Procedures and Microeconomic effects of Innovation, Journal of Economic Literature 26, pp 1120-1170.

Dosi G. (2004) A very reasonable objective still beyond our reach: Economics as an empirically disciplined social science. Forthcoming in Models of a Man: Essays in Memory of Herbert A. Simon. MIT Press.

Dosi, G. and L. Marengo (2000) The Tangled Discourse between Transaction Cost Economics and Competence-based Views of the Firm, in Foss N. and V. Mahnke (eds.) Op cit.

Dosi, G., R.R. Nelson and S.G. Winter (2000) Introduction, in G. Dosi, R.R. Nelson and S.G. Winter (eds.) The Nature and Dynamics of Organizational Capabilities. Oxford University Press.
Eisenhardt K and J.A. Martin (2000) Dynamic capabilities: What are they? Strategic Management Journal 21, pp 1105-1122.

Friedman, M. (1953) The Methodology of Positive Economics, in Essays in Positive Economics. Chicago: University of Chicago Press.

Hayek, F.A. (1945) The use of knowledge in society, in F.A. Hayek Individualism and Economic Order. University of Chicago Press.

Jacobides M.G. and L.M. Hitt (2001) Vertical scope revisited: Transaction costs versus capabilities and profit opportunities in mortgage banking, Working Paper 0117, Financial Institution Center, Wharton School, University of Pennsylvania.

Knight, F. (1921) Risk, Uncertainty and Profit. Boston, MA: Houghton Mifflin.

Langlois, R. (1992) Transactions-cost economics in real time, Industrial and Corporate Change 1(1), pp 99-127.

Langlois, R. and M. Cosgel (1993) Frank Knight on risk, uncertainty, and the firm, Economic Inquiry 31, pp 456-465.

Levinthal, D. and J.G. March (1993) The myopia of learning, Strategic Management Journal 14, pp 95-112.

Loasby, B. (1976) Choice, Complexity and Ignorance. Oxford: Oxford University Press.

Loasby, B. (1989) The Mind and Method of the Economist. Edward Elgar.

Mahoney, J. and R. Pandian (1992) The Resource-Based View Within the Conversation of Strategic Management. Strategic Management Journal Vol. 13, No. 5, pp 363-380. 
Marshall, A. (1925) Principles of Economics. London: McMillan.

March, J.G. (1991) Exploration and exploitation in organizational learning, Organization Science 2, pp 71-87.

March, J.G. (1994) A Primer on Decision Making. New York : Free Press.

March, J. G. (1996) A Scholars Quest, Stanford Graduate School of Business Magazine.

March, J.G. and H.A. Simon (1958) Organizations. New York: Wiley.

Morgenstern, O. (1951) Prolegomena to a Theory of Organization. RAND Research Memorandum, RM 5438. Santa Monica: The RAND Corporation.

Monteverde, K. and D.J. Teece (1982) Supplier switching costs and vertical integration in the U.S. automobile industry, The Bell Journal of Economics 13(1), pp 206-213.

Nelson, R. and S.G. Winter (1982) An Evolutionary Theory of Economic Change. Belknap Press: Cambridge.

Penrose, E. (1952) Biological Analogies in the Theory of the Firm, American Economic Review 42, pp 804-819.

Penrose, E. (1953) Biological Analogies in the Theory of the Firm: Rejoinder, American Economic Review 43 (4), pp 603-609.

Penrose E. (1959) The Theory of the Growth of the Firm. Oxford : Blackwell.

Prahalad, C. and G Hamel (1990) The Core Competence of the Corporation, Harvard Business Review.

Porter, M. (1996) What is strategy, Harvard Business Review.
Richardson, G.B. (1960) Information and Investment, Oxford University Press.

Richardson, G.B. (1972) The Organization of Industry, Economic Journal 82 (327), pp 883-896.

Rumelt, R. (1984) Towards a Strategic Theory of the Firm, in Lamb, R.B. (ed.) Competitive Strategic Management. Englewood Cliffs, NJ: Prentice Hall.

Rumelt, R., D. Schendel and D. Teece (1994) Introduction, in Fundamental Issues in Strategy. Boston: Harvard Business School Press.

Schumpeter, J. (1934) The Theory of Economic Development. Cambridge: Harvard University Press.

Schumpter, J. (1947) Theoretical Problems of Economic Growth, Journal of Economic History 7, pp 1-9.

Schumpeter, J. (1949) Economic theory and entrepreneurial history, in Harvard University Research Center in Entrepreneurial History, Change and the Entrepreneur. Boston, MA: Harvard University Press, pp 63-84.

Selznick, P. (1957) Leadership in Administration: A Sociological Interpretation. New York: Harper and Row.

Simon, H.A. (1991) Organizations and markets, Journal of Economic Perspectives 5, pp 25-44.

Simon, H.A. (1955) A behavioral model of rational choice, Quarterly Journal of Economics 69, pp 99-118.

Simon, H.A. (1993) Strategy and organizational evolution, Strategic Management Journal 14, pp 131-142. 
Teece, D. (1982) Towards an Economic Theory of the Multiproduct Firm, Journal of Economic Behavior and Organization 3, pp 39-63.

Teece, D.J. (1984) Economic analysis and strategic management, California Management Review 26(3), pp 87-110.

Teece, D.J. (1986) Profiting from technological innovation, Research Policy 15(6), pp 285-305.

Teece. D.J. (1990): Contributions and Impediments of Economic Analysis to the Study of Strategic Management, in Frederickson, J. (ed.) Perspectives on Strategic Management. Grand Rapids: Harper Business.

Teece, D.J. (1993) The dynamics of industrial capitalism: Perspectives on Alfred Chandler's Scale and Scope, Journal of Economic Literature 31, pp 199-225.

Teece, D.J. (1998) Capturing value from knowledge assets: The new economy, market for know how, and intangible assets, California Management Review 40(3), pp 55-79.

Teece, D. and G. Pisano (1994) The dynamic capabilities of firms: An introduction, Industrial and Corporate Change 3(3), pp 537-556.

Teece, D., G. Pisano and A. Shuen (1997) Dynamic capabilities and strategic management, Strategic Management Journal 18(7), pp 537-533.

Teece, D.J. and S.G. Winter (1984) The limits of neoclassical theory in management education, American Economic Review 74(2), pp 116-121.
Teece D., L. Pearce and C. Boerner (2002) Dynamic capabilities, competence, and the behavioral theory of the firm, in Augier M and J.G. March (eds.) The Economics of Choice, Change and Organization: Essays in Honor of Richard M. Cyert. Edward Elgar.

Walker, G. and D. Weber (1984) A transaction cost approach to make-or-buy decisions, Administrative Science Quarterly 29(3), pp 373-392.

Wernerfelt, B. (1984) A resource based view of the firm, Strategic Management Journal 5, pp 171-180.

Williamson, O.E. (1975) Markets and Hierarchies: Analysis and Antitrust Implications. New York: The Free Press.

Williamson, O.E. (1985) The Economic Institutions of Capitalism. New York: The Free Press.

Williamson, O.E. (1990) Chester Barnard and the Incipient Science of Organization, in Williamson (ed.) Organization Theory: From Chester Barnard to the Present and Beyond. New York: Oxford University Press.

Williamson, O.E. (1999) Strategy research: Governance and competence perspectives. Strategic Management Journal 20, pp 1087-1108.

Winter, S.G. (1964) Economic "Natural Selection" and the Theory of the Firm', Yale Economic Essays 4 (1), pp 225-72.

Winter, S.G. (1968) Towards a NeoSchumpterian Theory of the Firm. RAND Research Memorandum. Santa Monica: The RAND Corporation.

Winter, S. (1971) Satisficing, Selection and the Innovating Remnant, Quarterly Journal of Economics 85, pp 237-261. 
Winter, S.G. (1975) Optimization and Evolution in the Theory of the Firm, in Day, R. and T. Groves (eds.) Adaptive Economic Models. New York: Academic Press.

Winter, S.G. (1988) On Coase, Competence, and the Corporation, Journal of Law, Economics, and Organization 4(1), pp 163180.

Winter, S.G. (2000) The satisficing principle in capability learning, Strategic Management Journal 21, pp 981-996.

Winter, S. (2003) Understanding dynamic capabilities, Strategic Management Journal.

Zollo, M. and S. Winter (2002) Deliberate learning and the evolution of dynamic capabilities, Organizational Science 13(3), pp 339-351. 


\section{Published in the series Papers in Organization}

No. 1: Schultz, Majken (1991): Transitions Between Symbolic Domains in Organizations.

No. 2: Borum, Finn (1991): Innovating under Norms of Rationality.

No. 3: Pedersen, Jesper Strandgaard (1991): The Unisys Merger - When Lovers Meet or a Well-arranged Marriage?

No. 4: Hatch, Mary Jo (1991): The Dynamics of Organizational Culture.

No. 5: $\quad$ Kristensen, Peer Hull (1991): When Labour Defines Business Recipes.

No. 6: Westenholz, Ann (1991): Paradoxical Thinking and Change in the Frames of Reference.

No. 7: Ehrlich, Sanford B. and Mary Jo Hatch (1991): Where there is Smoke: Spontaneous Humor as an Indicator of Paradox and Ambiguity in Organizations.

No. 8: Mikkelsen, Flemming (1991): Industrial Conflict in Scandinavia 1848-1990.

No. 9: Borum, Finn and John K. Christiansen (1993): Actors and Structure in IS Projects: What makes Implementation happen?

No. 10: Larsen, Henrik Holt (1993): Experiential Learning in Management Development - A Danish Case Study

No. 11: Kreiner, Kristian and Majken Schultz (1993): Soft Cultures - Symbolism in International R\&D Projects

No. 12: Marginson, Paul (1993): The Multidivisional Structure and Corporate Control: Explaining the Degree of Corporate Co-ordination over Decisions on Labour Relations

No. 13: Hatch, Mary Jo and Majken Schultz (1993): Functionalism and Symbolism in Cultural Studies: From Theoretical Prisons to Methodological Interplay.

No. 14: Nielsen, J. C. Ry and Pål Repstad (1993): From Nearness to Distance - and Back: on analyzing your own organization.

No. 15: Mikkelsen, Flemming (1993): Strikes among Public Employees in Denmark

No. 16: Huard, Pierre Finn Borum (1993): Social Dynamics of a Novel Activity

- The Case of Prenatal Diagnosis in France.

No. 17: Hatch, Mary Jo (1994): Reading Irony in the Humor of a Management Team: Organizational Contradictions in Context.

No. 18: Scheuer, Steen (1994): HRM Under Collective Bargaining:

The Sociological Perspective. 
No. 19: Hegewisch, Ariane and Henrik Holt Larsen (1996): European Development in Public Sector Human Resource Management.

No. 20: Dobbin, Frank and John R. Sutton (1996): The Rights Revolution and Organizational Differentiation.

No. 21: Pedersen, Jesper Strandgaard and Frank Dobbin (1997): Constructing Organizations: Neoinstitutionalism and Organizational Culture.

No. 22: Larsen, Henrik Holt (1997): In Search of Management Development in Europe - from self-fulfilling prophecies to organizational competence.

No. 23: Borum, Finn (1997): Transforming Hospital Management: The (Im)possibility of Change.

No. 24: Hegland, Tore Jacob (1997): From a Thousand Flowers to Targeted Development.

No. 25: Norus, Jesper (1998): The Constitution of the Biotechnological Industry - the coevolution of networks and strategies.

No.26: Karnøe, Peter \& Raghu Garud (1998): Path Creation and Path Dependence in the Danish Wind Turbine Field.

No. 27: Christensen, Søren (1998): Hvad er “værdier” værd i institutionel organisationsanalyse?

No. 28: Steyaert, Chris (1998): 'Human, all too human management': Constructing 'the subject' in HRM.

No. 29: Scheuer, Steen (1998): Union Presence and Hours Worked.

No. 30: Kjær, Peter (1998): Fra bedriftscele til aktør-i-marked

Den driftsøkonomiske konstruktion af virksomheden 1915 - 1945

No.31: Augier, Mie \& Kristian Kreiner (1999): The Intelligence of Action: An Interview with James G.March

No. 32: Augier, Mie \& Kristian Kreiner (1999): Bringing Reality Back to Economics: An Interview with Herbert A. Simon

No. 33: Augier, Mie \& Kristian Kreiner (1999): Behavioral Economics and the Firm: An Interview with Richard M. Cyert

No. 34: Augier, Mie \& Kristian Kreiner (1999): Rationality, Institutions, and Economis Processes: An Interview with Richard N. Langlois

No. 35: Nygaard, Claus (1999): Strategic Actions of Embedded Small and Medium Sized Enterprises 
No. 36: Flüssel, Lanni \& Susse Georg (1999): Institutionalization of Environmental Concerns - Making the Environment Perform

No. 37: Sumita Raghuram, Manuel London \& Henrik Holt Larsen (2001): Flexible Employment Practices in Europe - Country versus Culture

No. 38: Sumita Raghuram \& Henrik Holt Larsen (2001): Human Resource Practices for Telework: The European Experience

No. 39: David Metz \& Ann Westenholz (2001): Identity Creation in Temporary and Scattered Work Communities in a Relational Perspective

No. 40: Kjell Tryggestad (2001): Reversible Statistics: The Making of Statistical Facts and Artifacts in Economics

No. 41: Sumita Raghuram, Manuel London \& Henrik Holt Larsen (2001): Links Between Organizational Characteristics and Change in and Flexible Employment Practices in European Organizations

No. 42: Sami Bloutaiba \& Jesper Standgaard Pedersen (2002): Creating MBA Identity - Between Field and Organization

No. 43: Per Vejrup-Hansen \& Flemming Agersnap (2002): Studieforløb og karriere. Sammenhæng mellem studielængde, andre studieforhold og lønudvikling blandt erhvervsøkonomiske kandidater

No. 44: Kjell Tryggestad (2002): Re-Drawing the Boundaries of Explanation: An Emerging Third Way

No. 45: J.C. Ry Nielsen \& Morten Ry (2002): The Danish Public Sector - An Endless Journey of Organisational Change

No. 46: Niels Christian Mossfeldt Nickelsen (2002): Moulding Singularity - Examining Multiplicity in Designing

No. 47: Raghu Garud \& Peter Karnøe (2002): Embedded and Distributed Agency in Technological Entrepreneurship

No. 48: Torben Elgaard Jensen (2003): Aktør-Netværksteori - en sociologi om kendsgerninger, karakker og kammuslinger

No. 49: José Alvarez, Carmelo Mazza, Jesper Strandgaard and Silviya Svejenova (2003):

Shielding Idiosyncrasy from Isomorphic Pressures: Towards Optimal Distinctivenes in European Film Making

No. 50: Henriette Langstrup Nielsen (2003): Self-Monitoring: IT and the Construction of the Competent Patient

No. 51: Mie Augier (2004): The Evolving Dynamics of Organizational Capabilities: An Interview with David J. Teece 
No. 52: Mie Augier \& David J. Teece (2004): Competencies, Capabilities and the Neoschumpeterian Tradition 